Article

\title{
Screening of Soybean Genotypes Based on Root Morphology and Shoot Traits Using the Semi-Hydroponic Phenotyping Platform and Rhizobox Technique
}

\author{
Mohammad Salim ${ }^{1,2}$, Yinglong Chen ${ }^{1} \mathbb{D}$, Heng Ye $^{3}$, Henry T. Nguyen $^{3} \mathbb{D}$, Zakaria M. Solaiman ${ }^{1, *(\mathbb{D})}$ \\ and Kadambot H. M. Siddique ${ }^{1}$ (D)
}

1 The UWA Institute of Agriculture, and UWA School of Agriculture and Environment, The University of Western Australia, Perth, WA 6001, Australia; mohammad.salim@research.uwa.edu.au (M.S.); yinglong.chen@uwa.edu.au (Y.C.); kadambot.siddique@uwa.edu.au (K.H.M.S.)

2 Bangladesh Agricultural Research Institute, Gazipur 1701, Bangladesh

3 Division of Plant Sciences and Technologies, College of Agriculture, Food and Natural Resources, University of Missouri, Columbia, MO 65211, USA; yehe@missouri.edu (H.Y.); nguyenhenry@missouri.edu (H.T.N.)

* Correspondence: zakaria.solaiman@uwa.edu.au

\section{check for}

updates

Citation: Salim, M.; Chen, Y.; Ye, H.; Nguyen, H.T.; Solaiman, Z.M.; Siddique, K.H.M. Screening of Soybean Genotypes Based on Root Morphology and Shoot Traits Using the Semi-Hydroponic Phenotyping Platform and Rhizobox Technique. Agronomy 2022, 12, 56. https:// doi.org/10.3390/agronomy12010056 Academic Editor: Maria del Carmen Salas Sanjuán

Received: 16 November 2021 Accepted: 23 December 2021 Published: 27 December 2021

Publisher's Note: MDPI stays neutral with regard to jurisdictional claims in published maps and institutional affiliations.

Copyright: (C) 2021 by the authors. Licensee MDPI, Basel, Switzerland. This article is an open access article distributed under the terms and conditions of the Creative Commons Attribution (CC BY) license (https:// creativecommons.org/licenses/by/ $4.0 /)$.

\begin{abstract}
Root-system architecture is vital for improving soybean (Glycine max L.) growth and nutrient uptake. We characterised root-system architecture and shoot traits of 30 soybean genotypes in a semi-hydroponic system 35 days after sowing (DAS) and validated eight genotypes with contrasting root-system architecture in $1.5 \mathrm{~m}$-deep rhizoboxes at the flowering stage. Among them, two genotypes were selected for evaluation through to maturity. Abundant variation (coefficient of variation values $\geq 0.25$ ) was observed in 11 of 13 measured roots and shoot traits during the early growth stage. After late growth stages, strong positive correlations were found between root traits and shoot traits, except for specific root length and diameter. Seed yield and yield traits at final harvest significantly differed between two contrasting soybean genotypes. The large-rooted genotype had a higher harvest index than the small-rooted genotype. Soybean genotypes with larger root systems had a long time to flowering than those with smaller root systems. Genotypes with large-root systems had 106\% more leaf area, and $245 \%$ more shoot dry weight than those with small systems, presumably due to high canopy photosynthesis to supply the demand for carbon assimilates to roots. Total root length, and root: shoot ratio-traits data collected in the rhizobox study, strongly correlated with the same traits in the semi-hydroponic phenotyping system. We found genetic variation and phenotypic plasticity in other root and shoot traits such as taproot depth, root dry weight, specific root length, and average root diameter among the tested genotypes. Phenology, particularly time to flowering, was associated with root system size. Some root and shoot traits in the semi-hydroponic phenotyping system at the seedling stage produced similar rankings at the later phenological (flowering) stage when grown in the soil-filled rhizoboxes. The soybean genotypes characterised by vastly different root traits could be used for further glasshouse and field studies to improve adaptation to drought and other specific environments.
\end{abstract}

Keywords: root system architecture; semi-hydroponic platform; 1.5 m-deep rhizoboxes; root dry weight; root length; cumulative root length (root tracing); leaf area; harvest index

\section{Introduction}

Roots are the primary organ for transferring soil resources to other plant parts, thereby controlling productivity [1]. Root-system architecture refers to the spatial configuration of the entire root system. It is generally quite complex and is different from morphology, root branching, and distribution [2]. Root architecture can include topography and 
distribution, which are usually easier to measure than other morphological traits. The architecture of a root system determines its exploration of spatial domains in the soil and its ability to respond to localised available nutrients in the soil/substrate [3]. However, studies for root growth and root-system architecture are often excluded in agricultural crop research because it is difficult to conduct root observations and monitoring in containers and field conditions during crop production [4]. Different methods and techniques for observing, studying, and quantifying root growth have been reported in the past nine decades. Many known methods of measuring root-system architecture are tedious and time-consuming, with generally low accuracy. Very few studies have used standard methods for measuring root systems [5]. Previously developed and validated semi-hydroponic phenotyping systems [6] have been used for high-throughput phenotyping of root morphological traits in several crop species at the early growth stage including narrow-leafed lupin [7], chickpea [8], wheat [9], barley [10] and soybean [11]. Root development and handling in rhizobox systems also can be challenging but preferred over field studies. Fortunately, many advances have been made in recent years to measure root traits, including easier, faster, reproducible, and more-descriptive techniques for wheat-root growth [12] and soybean [13]. However, it is difficult to observe, quantify, and interpret roots without jeopardising the native architecture [1].

Plants can adapt their roots under different environments, including stress, by integrating genetic improvement programs controlling root growth and development [14]. Subsoil root growth in water-limited soils is important for avoiding terminal drought stress in chickpea [15]. Natural variation in soybean root systems could be exploited to improve drought tolerance [16]. Genetic diversity in soybean root morphology and anatomy can affect water movement through root systems $[17,18]$. The benefit of a deep and prolific root system for drought tolerance has been reported for various crops, including wheat $[19,20]$, chickpea [8,21], and soybean [22-25].

Nutrient stress diminishes crop production. Phosphorus $(\mathrm{P})$ deficiency is a significant limitation for agricultural production [26,27]. To overcome low $\mathrm{P}$ availability, plants have evolved a complex array of tightly controlled adaptive mechanisms for maintaining $\mathrm{P}$ homeostasis, including maximising $\mathrm{P}$ absorption from the soil. Changing root architecture is a powerful tool for developing crop plants with an efficient P-acquisition ability. Root architecture is highly plastic in its developmental response to low P conditions. Several studies have shown that genotypic adaptations to P deficiency allow changes in root architecture that facilitate $\mathrm{P}$ acquisition $[13,28,29]$. For example, P-deficient plants can decrease primary root growth, resulting in a shallow root system that efficiently exploits topsoil resources [30]. However, this could inadvertently reduce water acquisition as water availability increases with soil depth under terminal drought. Little is known about the root system architecture, root and shoot traits, and adaptation mechanisms of soybean under stress.

Therefore, we examined the root-system architecture and shoot traits of soybean genotypes grown in the semi-hydroponic and deep soil-filled rhizoboxes. We conducted two independent but closely connected experiments using 30 soybean genotypes in a semi-hydroponic phenotyping system (experiment 1), followed by eight genotypes with contrasting root systems in soil-filled rhizoboxes (experiment 2). Plants were grown in a glasshouse allowing non-destructive root measurements and other root and shoot traits to test this hypothesis using previously described methods $[6,11,12]$. We evaluated whether the apparent genotypic differences in root and shoot traits at the seedling stage in the semihydroponic phenotypic study were reflected at the flowering stage when grown in soil-filled rhizoboxes. We hypothesised that genotypic differences in the root-system architecture and shoot traits of soybean seedlings grown under semi-hydroponic conditions are reproducible at a later phenological stage (flowering) when grown in soil-filled rhizoboxes. 


\section{Materials and Methods}

\subsection{Experiment 1-Semi-Hydroponic System \\ 2.1.1. Plant Materials and Growing Conditions}

The 30 soybean genotypes were obtained from the University of Missouri, Columbia, USA, with 18 considered drought tolerant, five salinity tolerant, three flood tolerant, and four had combined drought, salinity, and flood tolerance (Supplementary Table S1). The soybean genotypes were grown in a semi-hydroponic phenotypic system [6] in a completely randomised block design with three biological replicates. The experiment was carried out in a temperature-controlled glasshouse at The University of Western Australia (UWA). Seeds were sown in pots filled with washed river sand. After four days, three germinated seeds of each genotype were randomly transplanted into growth units of three bins. Each bin was filled with a $30 \mathrm{~L}$ solution containing (mM): K (1220), P (20), S (1802), Ca (600), $\mathrm{Mg}$ (200), Cu (0.2), Zn (0.75), Mn (0.75), B (5), Co (0.2), Na (0.06), Mo (0.03), Fe (20), and N (1000). An automatic irrigation system supplied the nutrient solution to the plant growth units. Periodic pumping was set as $10 \mathrm{~min}$ on $/ 5 \mathrm{~min}$ off during the day $(0600-1800 \mathrm{~h})$ and $5 \mathrm{~min}$ on/10 min off during the night (1800-0600 h). The solution was refreshed weekly.

\subsubsection{Trait Measurements}

Plants were harvested 35 days after transplanting. Root systems were photographed at harvest using a portable photographic technique, and taproot lengths were measured manually. After photographing, root subsamples were collected for morphological and architectural measurements by cutting the root system into $20 \mathrm{~cm}$ sections from the base. Shoots and roots were then dried in an air-forced oven at $70{ }^{\circ} \mathrm{C}$ for $72 \mathrm{~h}$ and weighed to determine shoot and root dry weights. Root subsamples were scanned in greyscale at 300 dpi using a desktop scanner (Epson Perfection V700, Long Beach, CA, USA). Root images were analysed using WinRhizo Pro software (v2009, Regent Instruments, Montreal, QC, Canada). The total root length was the sum of the root lengths in all sections from the same plant. Root diameter and surface areas were measured in two root-diameter classes $(0-0.25 \mathrm{~mm}$ and $>0.25 \mathrm{~mm})$. Root: shoot ratio is the ratio of root dry weight to shoot dry weight. Specific root length is the total root length per dry weight unit [11].

\subsection{Experiment 2-Soil-Filled Rhizoboxes}

\subsubsection{Plant Materials and Growing Conditions}

Eight soybean genotypes (PI 595362, PI 597387, PI 438500, PI 647960, PI 561271, PI 654356, PI 408105A, and PI 398595) were selected based on contrasting root-system architecture such as deep/fibrous roots, small/thin roots, fast wilting, drought-tolerant, drought-sensitive genotypes, and shoot traits (Supplementary Tables S1 and S2). The genotypes were grown in $1.5 \mathrm{~m}$-deep rhizoboxes (internal dimensions: $25 \mathrm{~cm}$ length $\times$ $5 \mathrm{~cm}$ width $\times 150 \mathrm{~cm}$ depth) filled with a soil-sand mixture (4:1 ratio) in a controlledenvironment glasshouse at UWA, Perth, Australia $\left(31^{\circ} 93^{\prime} \mathrm{S}, 115^{\circ} 83^{\prime}\right.$ E) from October 2020 to March 2021. The average daily air temperature was around $21^{\circ} \mathrm{C}$, maximum temperature $27{ }^{\circ} \mathrm{C}$, minimum temperature $14^{\circ} \mathrm{C}$, relative humidity $64 \%$, and $11-12 \mathrm{~h}$ of natural light. The experiment comprised a randomised complete block design with three replications. The polyvinyl chloride (PVC) rhizoboxes with acrylic glass sides were covered with removable black PVC sheets to avoid light exposure to roots and placed on steel stands, each holding two rhizoboxes, set $0.03 \mathrm{~m}$ apart. The rhizoboxes were placed at a $30^{\circ}$ angle to force the roots to grow along the acrylic glass side [31]. The rhizoboxes were rotated weekly to minimise spatial variability.

The experiment used a sandy loam soil collected from UWA's Farm, Ridgefield, Pingelly $\left(32^{\circ} 30^{\prime} \mathrm{S}, 116^{\circ} 59^{\prime} \mathrm{E}\right)$. The soil comprised $70.9 \%$ sand, $9.72 \%$ silt, and $19.4 \%$ clay, with the following chemical properties: pH $5.8\left(\mathrm{CaCl}_{2}\right), \mathrm{EC} 45 \mu \mathrm{sm}^{-1}, 3 \mathrm{mg} \mathrm{kg}^{-1}$ nitrate-N, $3 \mathrm{mg} \mathrm{kg}^{-1} \mathrm{P}, 52 \mathrm{mg} \mathrm{kg}^{-1} \mathrm{~K}$, and $10 \mathrm{~g} \mathrm{~kg}^{-1}$ organic carbon. The soil was dried and sieved to $<2 \mathrm{~mm}$ and mixed with air-dried river sand in a 4:1 ratio by weight using a cement mixture for uniformity [12,32]. Before adding the soil mix, $800 \mathrm{~g}$ of gravel was placed at the bottom 
of each rhizobox to cover the water drainage hole and avoid waterlogging. Each rhizobox was filled with $26 \mathrm{~kg}$ of soil-sand mix. Basal fertiliser (urea, triple superphosphate, and sulphate of potash), comprising $190 \mathrm{mg} \mathrm{kg}^{-1} \mathrm{~N}, 110 \mathrm{mg} \mathrm{kg}^{-1} \mathrm{P}$, and $130 \mathrm{mg} \mathrm{kg}^{-1} \mathrm{~K}$ dry soil, was mixed into the top $20 \mathrm{~cm}$ of soil in each rhizobox [33]. Each rhizobox received an equal amount of macro- and micro-nutrients from commercial liquid fertiliser (Thrive; Yates, Australia) on a \% w/v basis, with N (11), P (2.5), K (8), Mg (0.5), Mo (0.005), Cu (0.043), B (0.13), Zn (0.34), Fe (0.34), S (0.53), and Mn (0.26) as a top-dressing four weeks after emergence to ensure proper plant growth and development. The upper $5 \mathrm{~cm}$ of the soil mix in each rhizobox was inoculated with $3 \mathrm{~g}$ of peat-based rhizobia inoculum (Group H, New Edge Microbial, Albury, New South Wales, Australia) [34,35].

Soybean seeds were surface sterilised with $1 \% \mathrm{NaClO}$ solution, rinsed thoroughly with deionised water, placed on moistened filter paper inside Petri dishes, and seeds kept covered with aluminium foil to ensure darkness overnight to ease germination [34]. Two pre-germinated seeds were sown directly into the soil in each rhizobox (replicate), close to the glass wall and equidistant from one another. The rhizoboxes were checked daily for evidence of sprouting, and seedling rooting depth $(\mathrm{cm})$ was recorded. The water content $(w / w)$ at field capacity was $19.5 \%$ (when fully drained at rhizobox capacity). Depending on the weather, the plants were hand-watered each morning with deionised water to maintain the soil water content close to $80 \%$ field capacity and avoid excess water drainage. There were two harvests, one at flowering and the other at physiological maturity. The first harvest occurred at flowering 57 (PI 595362, PI 597387), 60 (PI 438500), 71 (PI 647960, PI 561271, PI 654356), 74 (PI 408105A), and 77 (PI 398595) DAS, and the second harvest (two genotypes only: PI 438500 and PI 561271) occurred at physiological maturity (158 DAS) when $95 \%$ of the pods had turned brown [29]. Soybean growth and development stages are described in [36].

\subsubsection{Shoot-Trait Measurements}

Days to the first flower, plant height, number of trifoliate leaves, primary branch number, mainstem node number, leaf area, stem dry weight, leaf dry weight, shoot dry weight, and total dry weight were recorded at first harvest. At maturity, pod number, number of seeds, mean seed weight, seed yield, and harvest index (\%) were measured. Plant height was calculated from the soil surface to the tip of the top leaf using a ruler. Leaf area was measured using a portable leaf-area meter (Li-3000, Li-COR, Biosciences, Lincoln, NE, USA). Pod and seed numbers per plant, seed number per pod, and seed yield were determined at final harvest (two genotypes only). One-hundred seed weights were determined. Harvest index (\%) was estimated as seed yield divided by the sum of shoot dry weight and seed yield, multiplied by 100 [37-39].

\subsubsection{Root Trait Measurements}

Visible roots via the glass panel in each rhizobox were traced onto transparent A4 film sheets at 10-day intervals from 10 days after emergence until the first harvest for all genotypes and up to 107 DAS for two genotypes (PI 438500 and PI 561271) when PI 561271 roots reached the bottom of the rhizobox. The transparent sheets were scanned using a portable scanner (JENKINS, PS4100, China) in $20 \mathrm{~cm}$ subsections at 600 pixels per $\mathrm{mm}$. Scanned images were analysed for cumulative root length, as previously described [11,12]. Destructive below-ground measurements included total root length, root dry weight, root length at different depths, root-length density, specific root length, root: shoot ratio, average root diameter, nodule number, and rooting depth. Each rhizobox was opened by removing the glass panel; the soil profile and root system were sampled in $20 \mathrm{~cm}$ sections from top to bottom by cutting through the soil with a carbon steel filling blade. Each section's roots were recovered from the soil following an established washing and sampling procedure for root trait measurement [31,40]. Roots were stored at $4{ }^{\circ} \mathrm{C}$ in a cold room until being scanned at 400 dpi per mm (EPSON Perfection V800 photo scanner, Long Beach, CA, USA). Scanned root images were used to measure root morphological traits $[6,8]$ using WinRhizo 
Pro software (v2009, Regent Instrument, Quebec, QC, Canada). Root-length density was calculated as root length divided by rhizobox soil volume [12]. Specific root length, an indirect measure of root system thickness, was estimated as root length divided by root dry weight [31]. After scanning, the root samples were oven-dried at $70{ }^{\circ} \mathrm{C}$ for $72 \mathrm{~h}$ to determine root dry weight for each section.

\subsection{Statistical Analyses}

The data were analysed to identify significant differences in root and shoot traits among the tested soybean genotypes. First, the normality of the data was tested using the Shapiro and Wilk [41] normality test. The data (log-transformed, if required) were then evaluated by one-way analysis of variance (ANOVA). Root traits with a coefficient of variation $(\mathrm{CV})$ value $\geq 0.25$ were selected to identify determinants of root architecture variability across genotypes in experiment 1 . Tukey's honest significance difference (HSD) in Tables 1-3, and and Fisher's least significance difference (LSD) tests in Figure 5 were used to compare genotypes. Cumulative root length data were analysed using the repeated-measures model. The model uses days and genotypes and their interactions. In experiment 2, Pearson's correlation analysis was undertaken for shoot and root traits (first harvest), with correlations considered significant if $p<0.05\left(^{*}\right), p<0.01\left(^{* *}\right)$, or $p<0.001\left(^{* * *}\right)$. The analyses were conducted using XLSTAT (2021.2.2 version), an internationally recognised statistical software package.

\section{Results}

\subsection{Experiment 1-Semi-Hydroponic Platform (Seedling Stage)}

The soybean genotypes showed significant phenotypic variation for various root and shoot traits (Figures 1 and 2). The coefficient of variation (CV) for total root length $(\mathrm{CV}=0.48)$, root dry weight $(\mathrm{CV}=0.59)$, root surface area $(\mathrm{CV}=0.50)$, root volume $(\mathrm{CV}=0.57)$, specific root length $(\mathrm{CV}=0.46)$, leaf number $(\mathrm{CV}=0.34)$, shoot height $(\mathrm{CV}=0.38)$, leaf branch number $(\mathrm{CV}=0.38)$, and shoot dry weight $(\mathrm{CV}=0.64)$ were all $p<0.05$ (Supplementary Table S2). The genotypes had an average root-growth rate (based on daily elongation of the taproot, $\mathrm{cm} \mathrm{d}^{-1}$ ) ranging from 0.77 (PI 483463) to 2.99 (PI 475822C), with mean value 1.95. Total root length ( $\mathrm{cm} \mathrm{plant}^{-1}$ ) ranged from 178 (PI 378702) to 1221 (PI 438500) (mean 579.35). Total taproot length (cm plant ${ }^{-1}$ ) ranged from 27 (PI 483463) to 104.67 (PI 475822C) (mean 68.19) (Supplementary Table S2, Figure 1). Root dry weight (mg plant ${ }^{-1}$ ) ranged from 23.50 (PI 483463) to 458 (PI 475822C) (mean 223). Specific root length ( $\mathrm{cm} \mathrm{mg}^{-1}$ ) ranged from 1.50 (PI 597387) to 8.88 (PI 483463) (mean 3.15) (Supplementary Table S2, Figure 1). Total root length and taproot length differed sevenfold and fourfold between the largest and the smallest genotypes, with a similar trend observed for root dry weight (Figure 1). Total root length positively correlated with root dry weight (Figure 1). Shoot height (cm plant $\left.{ }^{-1}\right)$ ranged from 4.0 (PI 483463) to 31.33 (PI 561271) (mean 12.28). Shoot dry weight $\left(\mathrm{mg} \mathrm{plant}^{-1}\right.$ ) ranged from 55 (PI 483463) to 1165 (PI 438489B) (mean 511.53) (Supplementary Table S2). 

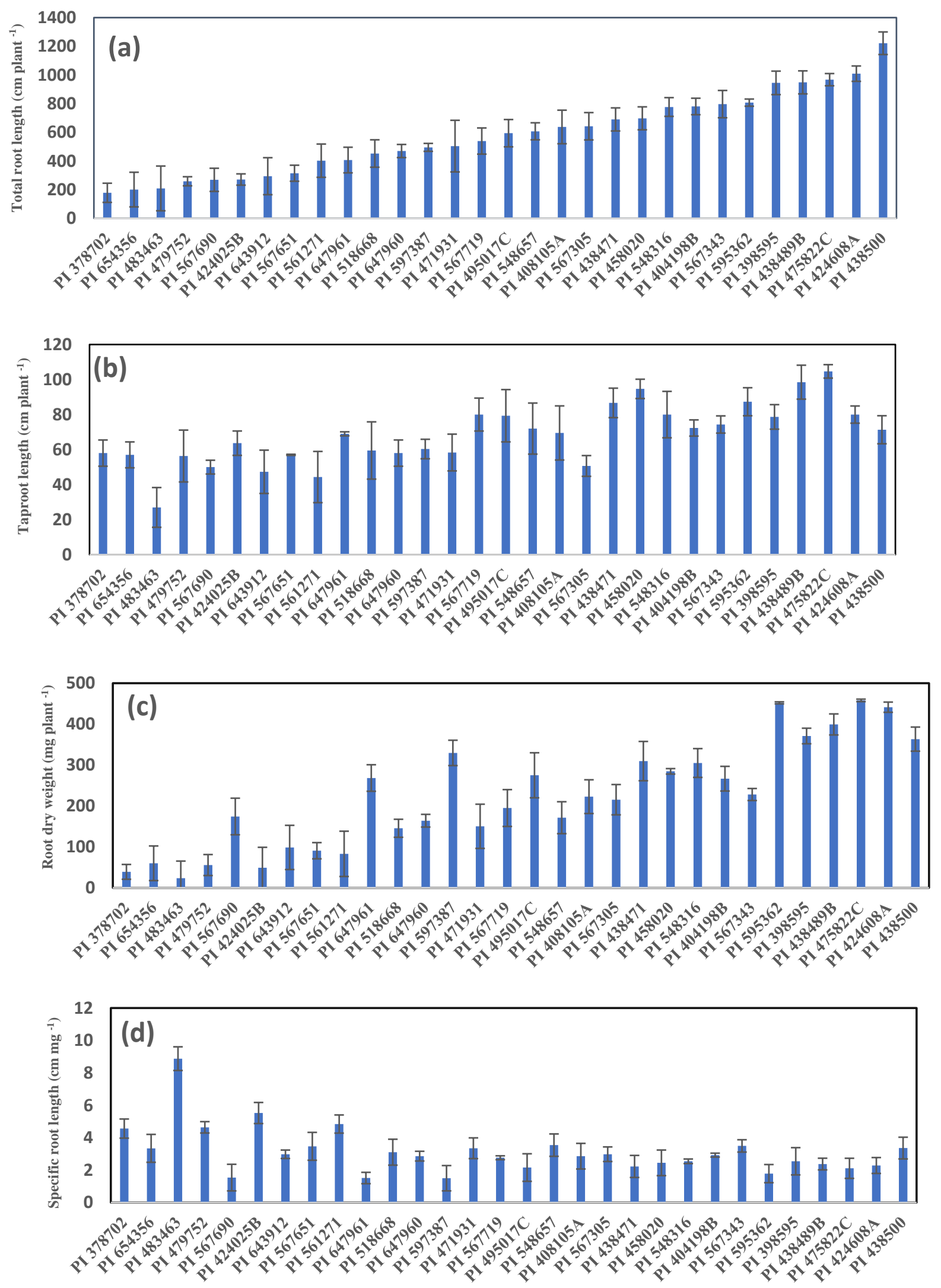

Figure 1. Genotypic variation in (a) total root length, (b) taproot length, (c) root dry weight, and (d) specific root length among 30 soybean genotypes grown in a semi-hydroponic phenotyping platform in a temperature-controlled glasshouse harvested 35 days after sowing. 


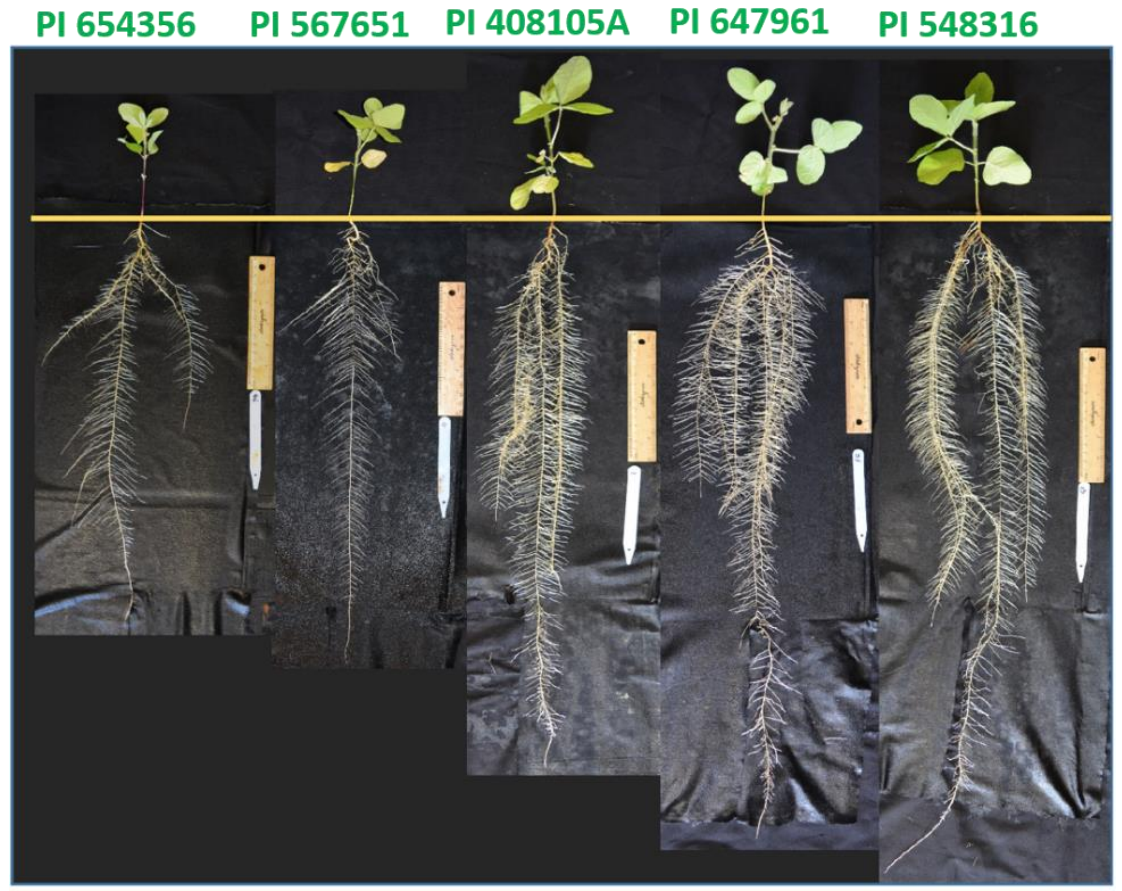

Figure 2. Example of soybean genotypes with contrasting root systems grown in a semi-hydroponic phenotyping platform in a temperature-controlled glasshouse harvested 35 days after sowing.

\subsection{Experiment 2-Soil-Filled Rhizoboxes (Flowering Stage)}

3.2.1. Phenology and Shoot Traits

Shoot traits differed significantly among the soybean genotypes $(p<0.001)$. The eight soybean genotypes emerged within 5-8 days after sowing (DAS). Days to first flower ranged from 55 DAS in PI 597387 to 75 DAS in PI 398595. Plant height ranged from $31 \mathrm{~cm}$ in PI 597387 and PI 438500 to $51 \mathrm{~cm}$ in PI 647960. The trifoliate leaf number varied from 11 in PI 597387 and PI 595362 to 34 in PI 561271 and PI 654356 (Table 1). Genotypes PI 597387, PI 595362, and PI 408105A had lesser primary branches than other genotypes. Genotypes (PI 561271 and PI 654356) had significantly $(p<0.001)$ more main stem nodes at the first flowering than the other genotypes (Table 1). Leaf area ranged from $704 \mathrm{~cm}^{2}$ plant $^{-1}$ in PI 647960 to $1989 \mathrm{~cm}^{2}$ plant ${ }^{-1}$ in PI 561271. Genotypes PI 561271 and PI 398595 had $106 \%$ more leaf area than the other six genotypes. Leaf dry weight ranged from $2.24 \mathrm{~g} \mathrm{plant}^{-1}$ in PI 597387 to $7.26 \mathrm{~g} \mathrm{plant}^{-1}$ in PI 561271 (Table 1). Stem dry weight ranged from $1.12 \mathrm{~g} \mathrm{plant}^{-1}$ in PI 597387 to $4.62 \mathrm{~g} \mathrm{plant}^{-1}$ in PI 654356. Shoot dry weight ranged from $3.36 \mathrm{~g} \mathrm{plant}^{-1}$ in PI 597387 to $11.61 \mathrm{~g} \mathrm{plant}^{-1}$ in PI 561271. Genotypes with large-root systems produced more shoot dry weight, leaf area, and leaf dry weight than those with small-root systems (Table 1). 
Table 1. Shoot traits of eight soybean genotypes grown in $1.5 \mathrm{~m}$-deep rhizoboxes. Values are the mean of three replicates (two plants per rhizobox). Means followed by different letters in the same column differ significantly at $p<0.05$ using Tukey's honest significance difference (HSD). ${ }^{* * *}$ indicates significant difference among genotypes at $p<0.001$.

\begin{tabular}{|c|c|c|c|c|c|c|c|c|c|}
\hline Genotype & $\begin{array}{c}\text { Days to } \\
\text { First } \\
\text { Flowering }\end{array}$ & $\begin{array}{l}\text { Plant } \\
\text { Height }\end{array}$ & $\begin{array}{c}\text { Trifoliate Leaf } \\
\text { Number }\end{array}$ & $\begin{array}{l}\text { Primary } \\
\text { Branch } \\
\text { Number }\end{array}$ & $\begin{array}{c}\text { Main Stem } \\
\text { Node } \\
\text { Number }\end{array}$ & Leaf Area & $\begin{array}{c}\text { Stem Dry } \\
\text { Weight }\end{array}$ & $\begin{array}{l}\text { Leaf Dry } \\
\text { Weight }\end{array}$ & $\begin{array}{l}\text { Shoot Dry } \\
\text { Weight }\end{array}$ \\
\hline & (days) & $(\mathrm{cm})$ & (leaf plant $^{-1}$ ) & (plant $^{-1}$ ) & (plant $^{-1}$ ) & $\begin{array}{c}\left(\mathrm{cm}^{2}\right. \\
\left.\text { plant }^{-1}\right)\end{array}$ & (g plant ${ }^{-1}$ ) & $\left(\right.$ g plant $\left.^{-1}\right)$ & $\left(\right.$ g plant $\left.^{-1}\right)$ \\
\hline PI 561271 & $69.7 \mathrm{~b}$ & $38 \mathrm{de}$ & $34 \mathrm{a}$ & $8.5 \mathrm{a}$ & $13.5 \mathrm{a}$ & 1989 a & $4.35 \mathrm{ab}$ & $7.26 \mathrm{a}$ & $11.61 \mathrm{a}$ \\
\hline PI 398595 & $75.0 \mathrm{a}$ & $45 \mathrm{bc}$ & $28 \mathrm{ab}$ & $7.0 \mathrm{a}$ & $13.1 \mathrm{a}$ & $1985 \mathrm{a}$ & $3.89 \mathrm{bc}$ & $6.84 \mathrm{a}$ & $10.74 \mathrm{ab}$ \\
\hline PI 654356 & $70.7 \mathrm{~b}$ & $39 \mathrm{~cd}$ & $34 \mathrm{a}$ & $8.2 \mathrm{a}$ & $13.5 \mathrm{a}$ & $1219 \mathrm{c}$ & $4.62 \mathrm{a}$ & $5.06 \mathrm{~b}$ & $9.68 \mathrm{~b}$ \\
\hline PI 408105A & $73.0 \mathrm{ab}$ & $48 \mathrm{ab}$ & $22 \mathrm{~b}$ & $3.8 \mathrm{c}$ & $9.3 \mathrm{bc}$ & $1523 \mathrm{~b}$ & $3.66 \mathrm{c}$ & $4.73 \mathrm{~b}$ & $8.39 \mathrm{c}$ \\
\hline PI 647960 & $70.0 \mathrm{~b}$ & $51 \mathrm{a}$ & $23 \mathrm{~b}$ & $6.7 \mathrm{ab}$ & $11.5 \mathrm{ab}$ & $704 \mathrm{e}$ & $3.69 \mathrm{c}$ & $4.77 \mathrm{~b}$ & $8.47 \mathrm{c}$ \\
\hline PI 438500 & $59.7 \mathrm{c}$ & 31 ef & $28 \mathrm{ab}$ & $9.0 \mathrm{a}$ & $11.7 \mathrm{ab}$ & $853 \mathrm{~d}$ & $2.35 \mathrm{~d}$ & $4.39 \mathrm{~b}$ & $6.74 \mathrm{~d}$ \\
\hline PI 595362 & $56.0 \mathrm{~cd}$ & 33 def & $11 \mathrm{c}$ & $4.2 \mathrm{bc}$ & $8.5 c$ & 766 de & $1.60 \mathrm{e}$ & $2.84 \mathrm{c}$ & $4.44 \mathrm{e}$ \\
\hline PI 597387 & $54.7 \mathrm{~d}$ & $31 \mathrm{f}$ & $11 \mathrm{c}$ & $4.3 \mathrm{bc}$ & $12.7 \mathrm{a}$ & $719 \mathrm{e}$ & $1.12 \mathrm{e}$ & $2.24 \mathrm{c}$ & $3.36 \mathrm{e}$ \\
\hline$p<0.05$ & $* * *$ & $* * *$ & $* * *$ & & $* * *$ & $* * *$ & $* * *$ & $* * *$ & $* * *$ \\
\hline
\end{tabular}

\subsubsection{Root Traits}

At 27 DAS, the cumulative visible root length ranged from $361 \mathrm{~cm} \mathrm{plant}^{-1}$ in PI 438500 to $199 \mathrm{~cm} \mathrm{plant}^{-1}$ in PI 561271. Thus, genotype PI 438500 had significantly more (24\%) cumulative root length than the other genotypes at the seedling stage (Figures 3 and 4 and Supplementary Table S3). The cumulative visible root length increased until 57 DAS, then started to decline, differing significantly $(p<0.001)$ from 67 DAS (Figure 3). At first flower, the cumulative visible root length ranged from $942 \mathrm{~cm} \mathrm{plant}^{-1}$ in PI 561271 (57 DAS) to $1500 \mathrm{~cm} \mathrm{plant}^{-1}$ in PI 438500 (57 DAS), which was significantly longer (48\%) than the other genotypes (Supplementary Table S3). At 107 DAS, the cumulative visible root length ranged from $3225 \mathrm{~cm}$ plant ${ }^{-1}$ in PI 438500 to $4248 \mathrm{~cm} \mathrm{plant}^{-1}$ in PI 561271, and differed significantly between the two genotypes $(p<0.05)$. The roots of PI 561271 reached the bottom of the rhizoboxes at 107 DAS, while the genotype PI 438500 almost stopped root growing and had not reached the bottom of the rhizobox at 107 DAS (Figure 4b). The estimated root penetration rates were $0.65 \mathrm{~cm} \mathrm{~d}^{-1}$ in PI 438500 and $1.37 \mathrm{~cm} \mathrm{~d}^{-1}$ in PI 561271 (Figure 4b, Table 3).

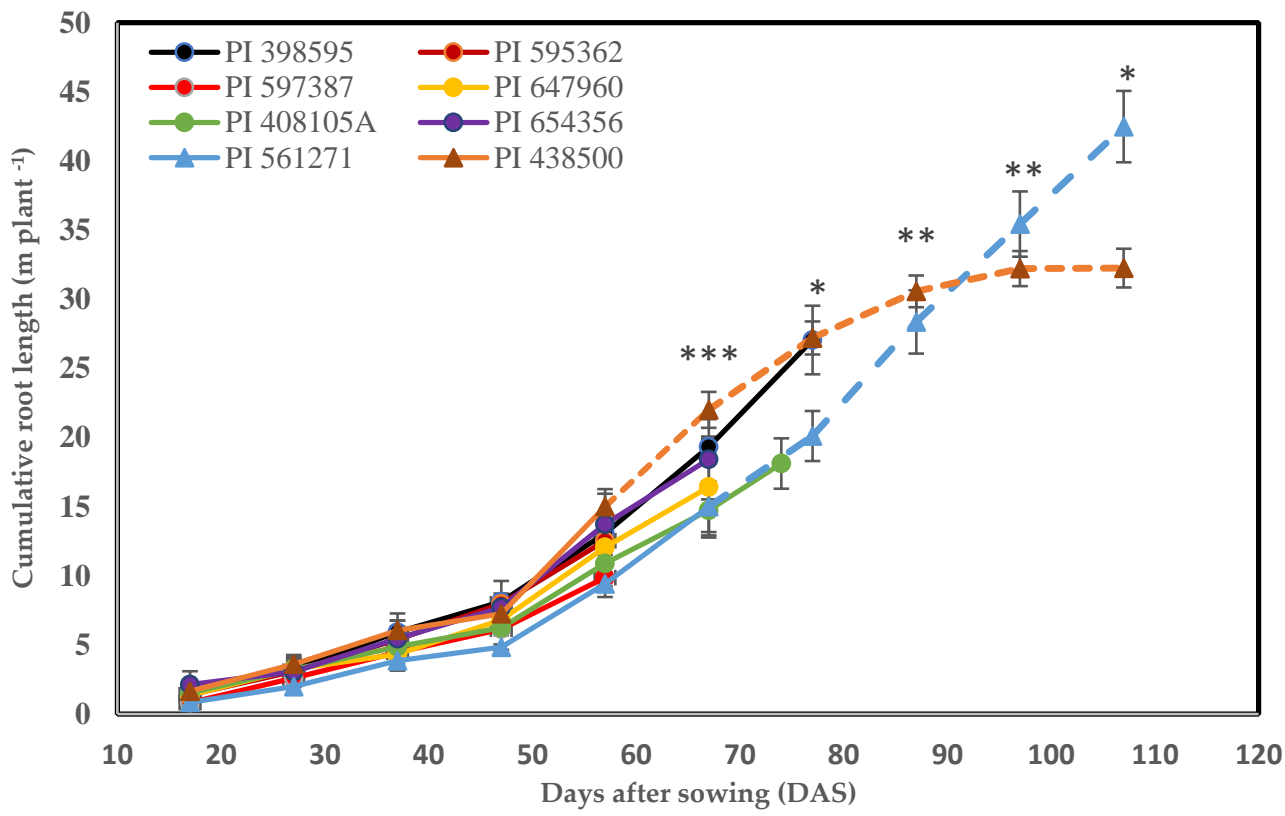

Figure 3. Non-destructively measured cumulative visible root length by root mapping through glass panels every 10 days from 17 days after sowing (DAS) until the first flower appeared in both plants in each rhizobox. Dashed lines are two genotypes (PI 438500 \& PI 561271) grown until the roots of 
PI 561271 reached the bottom of the rhizobox. Values are the mean \pm standard error of three replicates (two plants per rhizobox). ${ }^{*} * *$, and ${ }^{* * *}$ indicate significant difference among genotypes at $p<0.05$, $p<0.01$, and $p<0.001$, respectively.
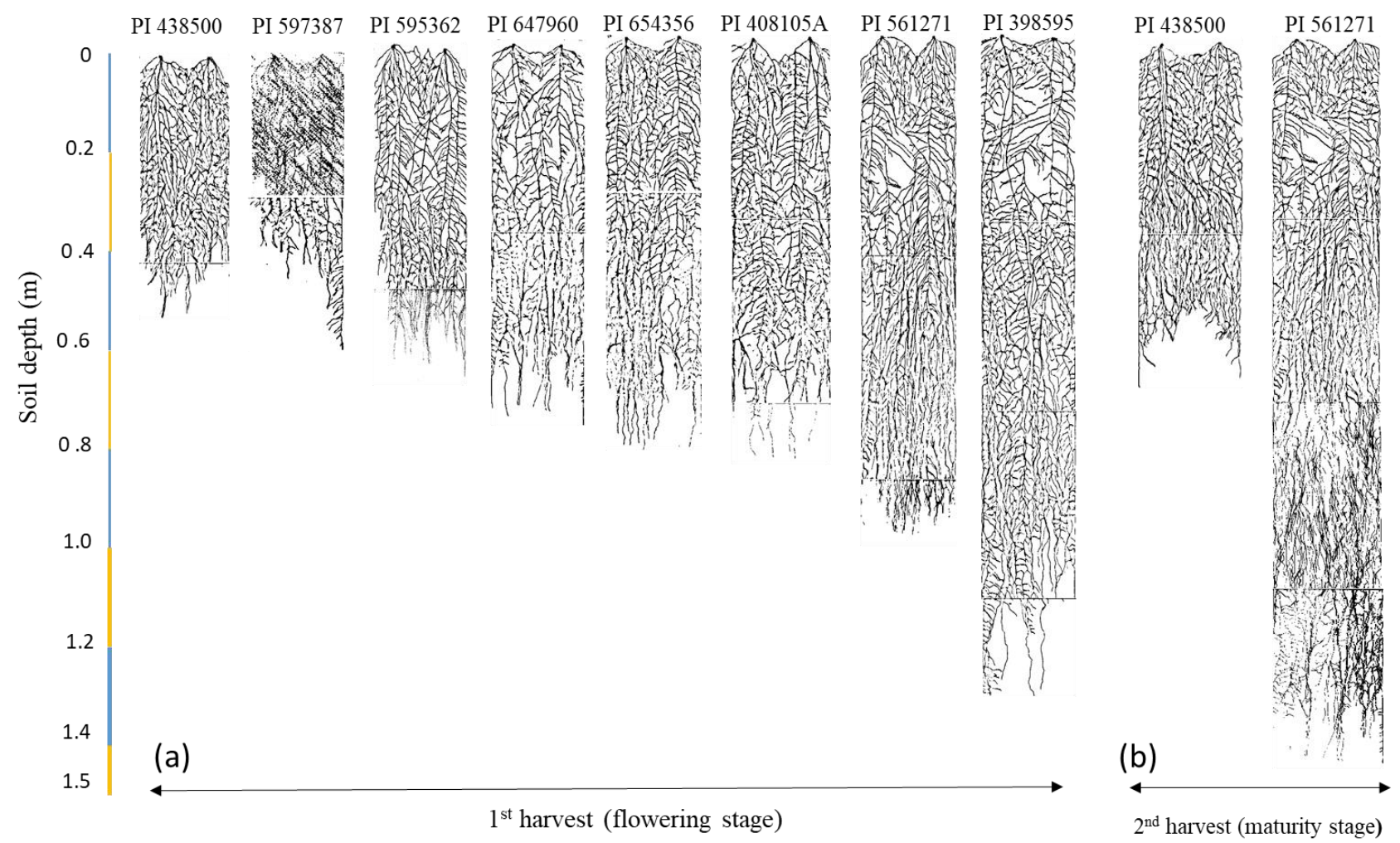

Figure 4. Images of traced root system visible through glass panels of $1.5 \mathrm{~m}$-deep rhizoboxes. (a) Eight soybean genotypes at flowering and (b) two genotypes at physiological maturity.

Total root length ranged from $87 \mathrm{~m} \mathrm{plant}^{-1}$ in PI 597387 to $266 \mathrm{~m} \mathrm{plant}^{-1}$ in PI 561271. Root-length density (RLD) ranged from $0.46 \mathrm{~cm} \mathrm{~cm}^{-3}$ in PI 597387 to $1.41 \mathrm{~cm} \mathrm{~cm}^{-3}$ in PI 561271. Genotypes (PI 561271 and PI 398595) had 90\% more total root length and 85\% higher RLD than the other six genotypes (Table 2). Root dry weight at first harvest ranged from $0.75 \mathrm{~g} \mathrm{plant}^{-1}$ in PI 597387 to $3.43 \mathrm{~g} \mathrm{plant}^{-1}$ in PI 561271 . Genotypes PI 561271 and PI 398595 produced $1.62 \mathrm{~g} \mathrm{plant}^{-1}$ (105\%) more root dry weight than the other six genotypes. Specific root length (SRL) ranged from $45 \mathrm{~m} \mathrm{~g}^{-1}$ in PI 654356 to $119 \mathrm{~m} \mathrm{~g}^{-1}$ in PI 597387. Genotype PI 597387 had $27 \mathrm{~m} \mathrm{~g}^{-1}$ higher SRL and thinner roots than the other genotypes, indicating that PI 654356 had thicker roots (51\%) than other genotypes (Table 2). Root: shoot ratio and root diameter did not differ significantly between the eight genotypes. Nodule numbers ranged from 115 in PI 561271 to 272 in PI 647960. Genotypes PI 647960, PI 654356, and PI 595362 had $79 \%$ or $53 \%$ more nodules per plant than the other five genotypes (Table 2). Rooting depth ranged from $55 \mathrm{~cm}$ in PI 438500 to $137 \mathrm{~cm}$ in PI 398595 $(p<0.05)$. The tested genotypes significantly varied in vertical rooting depth and root distribution pattern at both harvests (Tables 2 and 3, Figures 4 and 5, $p<0.05$ ). Most root length (\%) occurred in the top $0.2 \mathrm{~m}$ of the soil profile, which differed between genotypes (Figure 5). For instance, genotypes PI 561271 and PI 398595 had 34\% and 24\% of their total root length in the top $0.2 \mathrm{~m}$ of the soil profile compared with the genotypes PI 654356 (49\%) and PI 438500 (55\%). This study identified two large-rooted genotypes (PI 398595 and PI 561271), three medium-rooted genotypes (PI 654356, PI 408105A, PI 647960), and three small-rooted genotypes (PI 438500, PI 595362, PI 597387) based on rooting pattern, root distribution, and other traits (Figure $4 \mathrm{a}$ ). 
Table 2. Root traits of eight soybean genotypes grown in $1.5 \mathrm{~m}$-deep rhizoboxes. Values are the mean of three replicates (two plants per rhizobox). Means followed by different letters in the same column differ significantly at $p<0.05$ using Tukey's honest significance difference (HSD). ns: not significant, ** and ${ }^{* * *}$ indicate significant differences among genotypes at $p<0.01$ and $p<0.001$, respectively.

\begin{tabular}{|c|c|c|c|c|c|c|c|c|c|}
\hline Genotype & $\begin{array}{c}\text { Root } \\
\text { Length }\end{array}$ & $\begin{array}{l}\text { Root Dry } \\
\text { Weight }\end{array}$ & $\begin{array}{c}\text { Specific } \\
\text { Root } \\
\text { Length }\end{array}$ & $\begin{array}{c}\text { Root } \\
\text { Length } \\
\text { Density }\end{array}$ & $\begin{array}{c}\text { Root } \\
\text { Diameter }\end{array}$ & $\begin{array}{c}\text { Shoot Dry } \\
\text { Weight }\end{array}$ & $\begin{array}{l}\text { Root: } \\
\text { Shoot } \\
\text { Ratio }\end{array}$ & $\begin{array}{l}\text { Nodule } \\
\text { Number }\end{array}$ & $\begin{array}{l}\text { Rooting } \\
\text { Depth }\end{array}$ \\
\hline & $\left(\mathrm{m}\right.$ plant $\left.{ }^{-1}\right)$ & (g plant $^{-1}$ ) & $\left(\mathrm{mg} \mathrm{g}^{-1}\right)$ & $\left(\mathrm{cm} \mathrm{cm}^{-3}\right)$ & $(\mathrm{mm})$ & (g plant $\left.^{-1}\right)$ & & (plant $^{-1}$ ) & (cm) \\
\hline PI 561271 & $266 a$ & $3.43 \mathrm{a}$ & $77 \mathrm{abc}$ & $1.41 \mathrm{a}$ & $0.44 \mathrm{a}$ & $11.61 \mathrm{a}$ & $0.29 \mathrm{a}$ & $115 \mathrm{~b}$ & $106 \mathrm{~b}$ \\
\hline PI 398595 & $224 \mathrm{ab}$ & $2.90 \mathrm{ab}$ & $77 \mathrm{abc}$ & $1.19 \mathrm{ab}$ & $0.40 \mathrm{a}$ & $10.74 \mathrm{ab}$ & $0.27 \mathrm{a}$ & $152 \mathrm{ab}$ & $137 \mathrm{a}$ \\
\hline PI 654356 & $98 \mathrm{~cd}$ & $2.23 \mathrm{bc}$ & $45 c$ & $0.52 \mathrm{~cd}$ & $0.47 \mathrm{a}$ & $9.68 \mathrm{~b}$ & $0.23 \mathrm{a}$ & $200 \mathrm{ab}$ & $84 \mathrm{~cd}$ \\
\hline PI 408105A & $183 \mathrm{~b}$ & $1.92 \mathrm{~cd}$ & $100 \mathrm{ab}$ & $0.97 \mathrm{~b}$ & $0.42 \mathrm{a}$ & $8.39 \mathrm{c}$ & $0.22 \mathrm{a}$ & $171 \mathrm{ab}$ & $86 \mathrm{c}$ \\
\hline PI 647960 & $134 \mathrm{c}$ & $1.75 \mathrm{~cd}$ & $76 \mathrm{bc}$ & $0.71 \mathrm{c}$ & $0.49 \mathrm{a}$ & $8.47 c$ & $0.20 \mathrm{a}$ & $272 a$ & 80 cde \\
\hline PI 438500 & $138 \mathrm{c}$ & 1.45 cde & $96 \mathrm{ab}$ & $0.73 \mathrm{c}$ & $0.44 \mathrm{a}$ & $6.74 \mathrm{~d}$ & $0.21 \mathrm{a}$ & $142 \mathrm{~b}$ & $55 \mathrm{f}$ \\
\hline PI 595362 & $116 \mathrm{~cd}$ & $1.16 \mathrm{de}$ & $101 \mathrm{ab}$ & $0.62 \mathrm{~cd}$ & $0.48 \mathrm{a}$ & $4.44 \mathrm{e}$ & $0.26 \mathrm{a}$ & $209 \mathrm{ab}$ & 68 def \\
\hline PI 597387 & $87 \mathrm{~d}$ & $0.75 \mathrm{e}$ & $119 a$ & $0.46 \mathrm{~d}$ & $0.44 \mathrm{a}$ & $3.36 \mathrm{e}$ & $0.22 \mathrm{a}$ & $163 \mathrm{ab}$ & $65 \mathrm{ef}$ \\
\hline$p<0.05$ & $* * *$ & $* * *$ & $* * *$ & $* * *$ & ns & $* * *$ & ns & $* *$ & $* * *$ \\
\hline
\end{tabular}

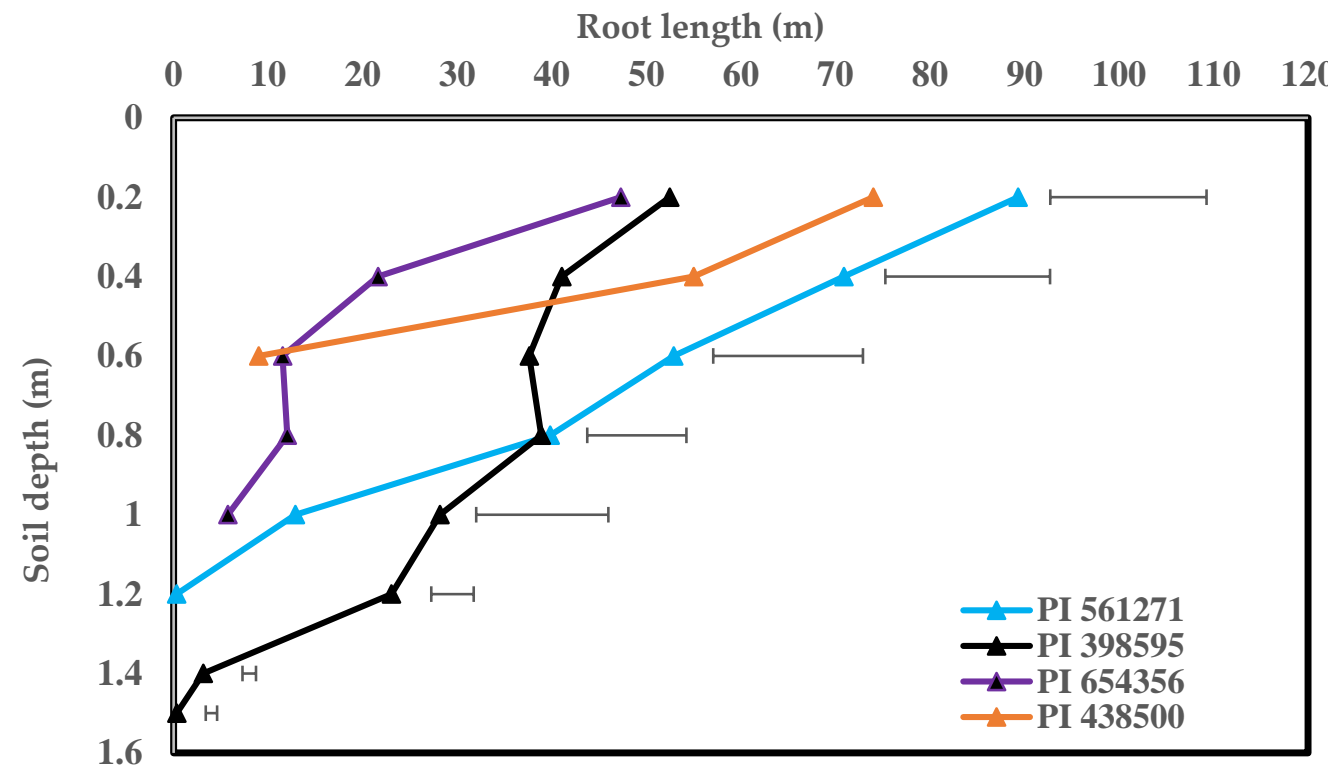

Figure 5. Destructively measured section-wise root lengths in soil profiles $(0.2 \mathrm{~m}$ sections from top to bottom of each rhizobox) of four soybean genotypes at flowering. Horizontal bars represent least significant difference (LSD) at $(p<0.05)$ for genotype comparisons at each section increment in the soil profile.

\subsubsection{Relationship between Shoot and Root Traits at Rhizoboxes (Flowering Stage)}

Days to first flower positively correlated with stem dry weight, leaf dry weight, leaf area, shoot dry weight, root dry weight, total root length, root-length density (RLD), and cumulative root length $(\mathrm{r}=0.90,0.80,0.70,0.88,0.72,0.58,0.58$, and 0.80 , respectively; $p<0.001)$ and negatively correlated with specific root length (SRL) $(\mathrm{r}=-0.56 ; p<0.01)$. Leaf area positively correlated with shoot dry weight, root dry weight, root: shoot ratio, total root length, RLD, and cumulative root length $(r=0.80,0.87,52,0.87,0.87$, and 0.68 , respectively; $p<0.001)$. Root dry weight positively correlated with root: shoot ratio, total root length, RLD, and cumulative root length $(\mathrm{r}=0.63,0.84,0.84$, and 0.62 , respectively; $p<0.001)$, and negatively correlated with SRL $(\mathrm{r}=-0.63)$. Root: shoot ratio positively correlated with total root length $(\mathrm{r}=0.53 ; p<0.001)$ and $\operatorname{RLD}(\mathrm{r}=0.53 ; p<0.001)$. Total root length positively correlated with $\operatorname{RLD}(\mathrm{r}=0.98 ; p<0.001)$ and cumulative root length $(\mathrm{r}=0.51 ; p<0.01)$, while SRL negatively correlated with cumulative root length $(\mathrm{r}=-0.46$; $p<0.05)$. Root-length density positively correlated with cumulative root length $(\mathrm{r}=0.51$; $p<0.01$ ), while average root diameter did not correlate with any of the measured shoot and root traits (Figure 6). 


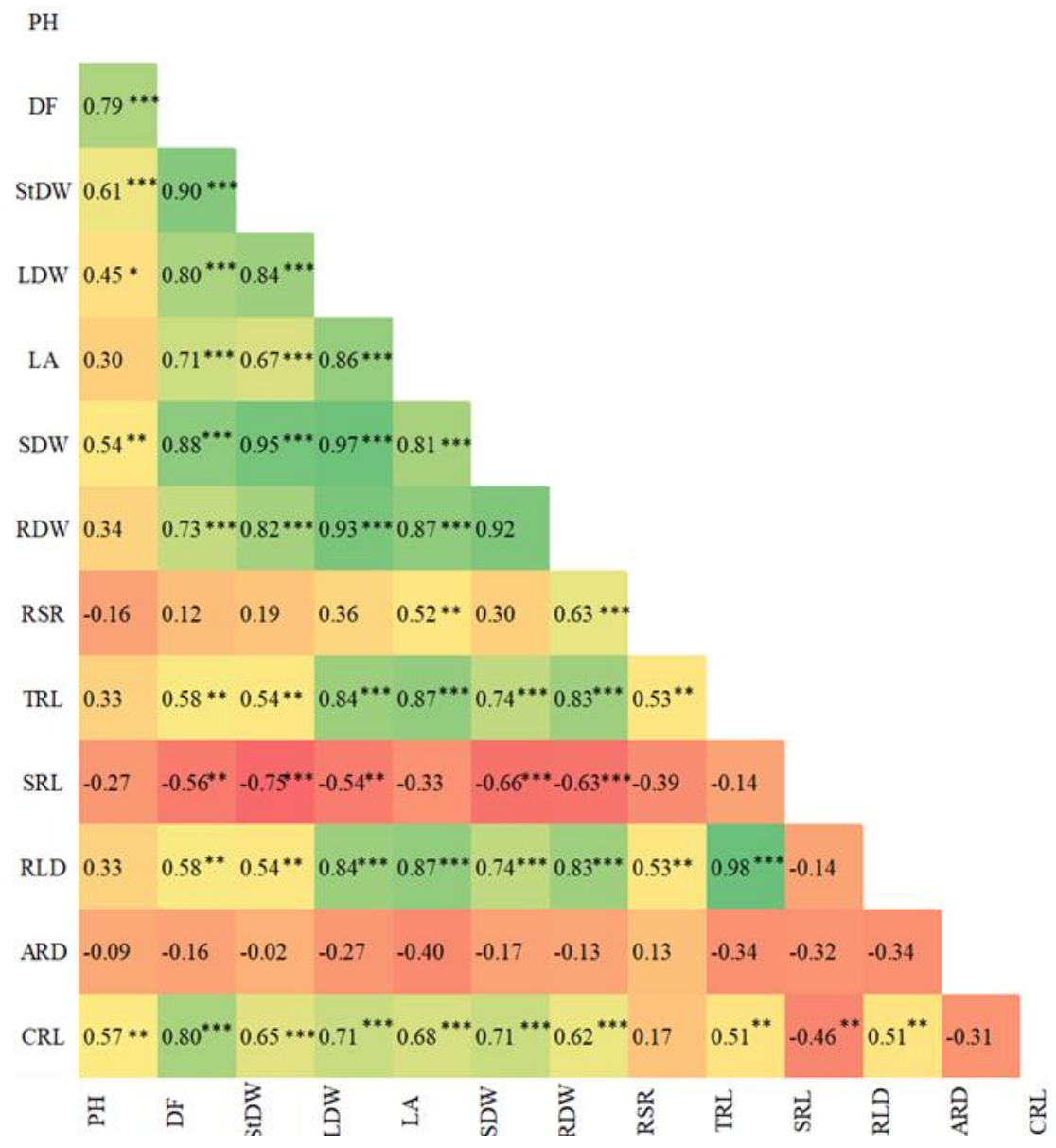

Figure 6. Pearson's correlations (r) for 13 root and shoot traits in soybean genotypes. ***, and *** indicate significant correlations at $p<0.05, p<0.01$, and $p<0.001$, respectively. $\mathrm{PH}=$ plant height, $\mathrm{DF}=$ days to first flower, StDW = stem dry weight, LDW = leaf dry weight, LA = leaf area, SDW = shoot dry weight, RDW = root dry weight, RSR = root: shoot ratio, TRL = total root length, $\mathrm{SRL}=$ specific root length, $\mathrm{RLD}=$ root-length density, $\mathrm{ARD}=$ average root diameter, $\mathrm{CRL}$ = cumulative root length.

3.2.4. Yield and Yield-Contributing Traits of Two Soybean Genotypes at Maturity Stage

At maturity, yield and yield-contributing traits (except root: shoot ratio) differed significantly between soybean genotypes (Table 3). Genotype PI 561271 produced more root and shoot biomass than PI 438500. Genotype PI 561271 yielded $8.47 \mathrm{~g} \mathrm{seed} \mathrm{plant}^{-1}$, six times higher than PI 438500. Similarly, PI 561271 produced 3.3 seeds per pod, 74\% more than PI 438500. Genotype PI 561271 produced 27.7 pods per plant, sevenfold more than PI 438500. In contrast, PI 438500 made 17.1 g per 100 seeds, 85\% more than PI 56127. At physiological maturity, PI 561271 had deeper rooting depth and continuous fast root growth and development after flowering $(146.7 \mathrm{~cm})$ than PI 438500 , which almost stopped root growth at flowering $(69.7 \mathrm{~cm})$ (Figure $4 \mathrm{~b})$. The highest harvest index was observed in PI 561271 rather than PI 438500 (Table 3). 
Table 3. Yield and yield-contributing traits of two soybean genotypes (PI 438500, PI 561271) grown in $1.5 \mathrm{~m}$-deep rhizoboxes and harvested 158 days after sowing (DAS). Values are mean \pm standard error of three replicates (two plants per rhizobox). Means followed by different letters in each column differ significantly at $p<0.05$ using Fisher's least significant difference. ns: not significant, ${ }^{*}{ }^{* *}$ and

$* * *$ indicate significant difference among genotypes at $p<0.05, p<0.01$, and $p<0.001$, respectively.

\begin{tabular}{|c|c|c|c|c|c|c|c|c|c|c|}
\hline Genotype & $\begin{array}{l}\text { Shoot Dry } \\
\text { Weight }\end{array}$ & $\begin{array}{c}\text { Root Dry } \\
\text { Weight }\end{array}$ & $\begin{array}{c}\text { Total Dry } \\
\text { Weight }\end{array}$ & $\begin{array}{l}\text { Root: } \\
\text { Shoot } \\
\text { Ratio }\end{array}$ & $\begin{array}{c}\text { Pod } \\
\text { Number }\end{array}$ & $\begin{array}{c}\text { Seed } \\
\text { Numbers }\end{array}$ & $\begin{array}{l}\text { 100-Seed } \\
\text { Weight }\end{array}$ & Seed Yield & $\begin{array}{l}\text { Rooting } \\
\text { Depth }\end{array}$ & $\begin{array}{l}\text { Harvest } \\
\text { Index }\end{array}$ \\
\hline & $\left(\right.$ g plant $\left.^{-1}\right)$ & g plant $\left.^{-1}\right)$ & (g plant $\left.^{-1}\right)$ & & (plant $\left.^{-1}\right)$ & $\left(\operatorname{pod}^{-1}\right)$ & (g) & (g plant $^{-1}$ ) & $(\mathrm{cm})$ & $(\%)$ \\
\hline PI 561271 & $13.3 \pm 0.1 \mathrm{a}$ & $4.8 \pm 0.1 \mathrm{a}$ & $18.1 \pm 0.7 \mathrm{a}$ & $0.35 \pm 0.05$ & $27.7 \pm 1.6 \mathrm{a}$ & $3.3 \pm 0.2 \mathrm{a}$ & $9.26 \pm 0.12 b$ & $\begin{array}{c}8.47 \pm 0.05 \\
a\end{array}$ & $\begin{array}{c}146.7 \pm 2.0 \\
\mathrm{a}\end{array}$ & $38.9 \pm 0.5 \mathrm{a}$ \\
\hline $\begin{array}{l}\text { PI } 438500 \\
p \text { value }\end{array}$ & $\begin{array}{c}11.3 \pm 03 b \\
0.03^{*}\end{array}$ & $\begin{array}{c}2.8 \pm 0.1 \mathrm{~b} \\
0.035^{*}\end{array}$ & $\begin{array}{c}14.0 \pm 0.3 b \\
0.01^{* *}\end{array}$ & $\begin{array}{c}0.24 \pm 0.02 \\
\text { a } \\
\text { ns }\end{array}$ & $\begin{array}{c}4.0 \pm 0.3 \mathrm{~b} \\
0.001^{* * *}\end{array}$ & $\begin{array}{c}1.9 \pm 0.2 \mathrm{~b} \\
0.007^{* *}\end{array}$ & $\begin{array}{c}17.10 \pm 0.14 \\
\mathrm{a} \\
0.004\end{array}$ & $\begin{array}{c}1.3 \pm 0.09 \mathrm{~b} \\
0.001^{* * *}\end{array}$ & $\begin{array}{c}69.7 \pm 3.0 \mathrm{~b} \\
0.001 * * *\end{array}$ & $\begin{array}{c}10.3 \pm 0.4 \mathrm{~b} \\
0.01 \text { ** }\end{array}$ \\
\hline
\end{tabular}

\subsection{Trait Consistency between the Two Experiments}

Some experimental parameters were highly correlated (for the same traits) between the semi-hydroponic experiment (experiment 1 ) and rhizobox experiment (experiment 2). Strong correlations occurred between experiments for total root length, and root: shoot ratio harvested at 35 DAS (semi-hydroponic) and 57-77 DAS (rhizoboxes) $(p<0.05)$. No significant correlations occurred for taproot depth, root dry weight, average root diameter, and specific root length, suggesting phenotypic plasticity for these traits in the tested soybean genotypes (Table 4).

Table 4. Correlation (r) and probability values $(p)$ of seven parameters selected in the same eight soybean genotypes grown in a semi-hydroponic system (experiment 1 ) and soil-filled rhizoboxes (experiment 2).

\begin{tabular}{ccc}
\hline Parameters & $\mathbf{r}$ & $p$ \\
\hline Taproot depth & $-0.06 \mathrm{~ns}$ & 0.89 \\
Shoot dry weight & $-0.68^{*}$ & 0.05 \\
Root dry weight & $-0.53 \mathrm{~ns}$ & 0.17 \\
Root shoot ratio & $0.71^{*}$ & 0.04 \\
Total root length & $0.67^{*}$ & 0.05 \\
Average root diameter & $0.38 \mathrm{~ns}$ & 0.35 \\
Specific root length & $-0.55 \mathrm{~ns}$ & 0.15
\end{tabular}

Extracted data from Pearson's correlation matrix. Pearson's correlation analysis was performed on each parameter in the two experiments, respectively. Correlation is significant, ${ }^{*} p \leq 0.05$; ns is non-significant.

\section{Discussion}

\subsection{Characterising Soybean Genotypes with Contrasting Root System Architecture}

We hypothesised that genotypic differences in the root-system architecture and shoot traits of soybean seedlings grown under semi-hydroponic conditions are reproducible at a later phenological stage (flowering) when grown in soil-filled rhizoboxes. To answer these questions, the first phenotyping study in a semi-hydroponic system revealed significant variations in different root and shoot traits of 30 soybean genotypes, and in the second study, eight genotypes in soil-filled rhizoboxes differed. The soybean root system has a taprootdominant rooting pattern comprising first-order lateral roots and densely or sparsely distributed second-order branches, as recently characterized in 171 soybean genotypes popularized in the Yangtze and Huaihe River regions, eastern China [11]. Our semihydroponic study showed that genotypes PI 475822C, PI 438479B, PI 458020, and PI 595362 developed larger taproots than the other genotypes. Genotypes PI 483463 and PI 561271 had relatively small roots and the genotype PI 438500 had more total root length than other genotypes during early growth. Large-rooting genotypes had nearly fourfold-longer taproots and root-branching zones than the small-rooting genotypes. In a similar study using a semi-hydroponic system, soybean, white lupin, and narrow-leafed lupin exhibited prolific and large roots [13]. 
Non-destructive root measurements using root mapping revealed significant differences in root length at the vegetative stage between genotypes grown in soil-filled rhizoboxes. Moreover, root-system architecture significantly differed between genotypes, particularly after 47 DAS when the genotypes moved from the vegetative to reproductive stage. Studies have shown that root growth in rhizoboxes did not significantly differ between wheat genotypes up to 35 DAS [12]. However, large-rooted genotypes (PI 398595 and PI 561271) had more cumulative root length, total root length, total root dry weight, root branching, and rooting depth than small-rooted genotypes (PI 438500, PI 595362, and PI 597387). In this study, rooting depth, cumulative root length, total root length, specific root length, root-length density, and root dry weight differed significantly between largeand small-root-system genotypes.

\subsection{Relationship between Root-System Architecture and Shoot Traits}

Genotypes with large-root systems produced more leaf area, leaf dry weight, stem dry weight, shoot dry weight, and root dry weight and higher root: shoot ratio than those with small-root systems. It is likely that the large-rooted genotypes (PI 398595 and PI 561271), with more leaf area and leaf dry weight, would have a higher rate of photosynthesis per plant and more $\mathrm{C}$ assimilates allocated to roots, as reported for soybean [11,13] and wheat [12]. The higher root: shoot ratio in genotypes (PI 398595 and PI 561271) with largeroot systems indicates that these genotypes allocated more in total plant dry weight to roots than those with small-root systems. Genotypic differences in the root: shoot ratio may be due to the delayed reproductive development in genotypes (PI 398595 and PI 561271) with large-root systems, extending the investment period to root dry weight by up to 15 days, compared with genotypes with small-root systems (PI 438500, PI 595362, and PI 597387). At flowering time, soybean genotypes with less root dry weight and total root length started flowering 17 days earlier than genotypes (PI 398595 and PI 561271) with more root dry weight and total root length. The slower-growing genotypes have more time for root growth and extension than the faster-growing genotypes. Legume species had more shoot dry weight, leaf area, and total root length than graminoid species [13]. The rhizobox study demonstrated the relationship between shoot and root traits and their significant positive correlations among tested traits of soybean genotypes. Dayoub et al. [42] showed that total root length positively correlated with shoot dry weight and shoot length in soybean. Specific root length negatively correlated with other root and shoot traits observed in soybean [43]. Genotypes with large-root systems produced higher yield and components than those with small-root systems reported $[29,44]$.

\subsection{Data Validation between the Two Experiments}

The present study showed that some root and shoot traits measured at the seedling stage in the semi-hydroponic system were reproducible at a later phenological (flowering) stage in soil-filled rhizoboxes. Similarly, narrow-leafed lupin genotypes were consistently ranked for several important root traits grown in various environments in Western Australia [45]. Three soybean genotypes had consistent root biomass and root length in a semi-hydroponic system and soil-filled columns [11]. However, in our study, some shoot and root traits differed between the two experiments, which may explain how different genotypes grew with varying media of growth, genotypic variation, and phenotypic plasticity in some root and shoot traits $[13,46]$. The growth media likely influences plant growth due to the availability and distribution of plant-available nutrients in the root surroundings $[7,47]$. Therefore, characterising root and shoot traits is essential for breeding new varieties and increasing legume production in stressed environments.

\section{Conclusions}

Large variations in shoot and root traits were identified among the 30 soybean genotypes. The selected eight genotypes showed intrinsic plasticity in some traits at different growth stages in the deep soil-filled rhizoboxes. Several roots and shoot traits, particularly 
the total root length, shoot dry weight, and root: shoot ratio measured at the seedling stage in a semi-hydroponic phenotyping system were reproducible at a later phenological (flowering) stage in soil-filled rhizoboxes. The outputs of this study could form a basis for future soybean selection and breeding programs aiming for producing soybean cultivars with highly efficient resource uptake and better adaptation to edaphic stress. Since rootsystem architecture is the key factor affecting soybean yield under water and low-P stress, as discussed above, further investigations on the role of root traits in water and P uptake under drought and low-P environments are required.

Supplementary Materials: The following supplementary materials are available online at https:/ / www.mdpi.com/article/10.3390/agronomy12010056/s1, Supplementary Table S1: List of genotypes used in the semi-hydroponic system for phenotyping root-trait variability (experiment 1 ) and rhizobox study (experiment 2), Supplementary Table S2: Descriptive statistics for root and shoot traits of the 30 soybean genotypes used in the semi-hydroponic study ( $\mathrm{CV} \geq 0.25$ in Bold), and Supplementary Table S3: Cumulative visible root length by root mapping through glass panels every 10 days from 17 days after sowing (DAS) to first flower time (eight genotypes) and maturity (two genotypes) once the roots of genotype PI 56127 reached the bottom of the 1.5 m-deep rhizoboxes (107 DAS). Values are the mean \pm standard error of three replicates (two plants per rhizobox). ns: not significant. *,$* *$, and $* * *$ indicate significant differences among genotypes at $p<0.05, p<0.01$, and $p<0.001$, respectively.

Author Contributions: Conceptualisation, Y.C., H.T.N., Z.M.S. and K.H.M.S.; Methodology, Y.C., H.Y., H.T.N., Z.M.S. and K.H.M.S.; Investigation and imaging, M.S. and Y.C.; Data curation, M.S. and Y.C.; Resource, H.Y., H.T.N. and K.H.M.S.; Writing-original draft, M.S.; Writing-review and editing, Y.C., H.Y., H.T.N., Z.M.S. and K.H.M.S. All authors have read and agreed to the published version of the manuscript.

Funding: This research received no external funding.

Institutional Review Board Statement: Not Applicable.

Informed Consent Statement: Not Applicable.

Data Availability Statement: The data presented in this article are available on request from the corresponding author.

Acknowledgments: Mohammad Salim gratefully acknowledges the support and funding from the Bangabandhu Science and Technology Fellowship Trust (BSTFT) scholarship from the Bangladesh Government and a UWA postgraduate award throughout the research period. We also acknowledge the technical assistance of Robert Creasy and Bill Piasini for the plant-growth facility.

Conflicts of Interest: The authors declare no conflict of interest.

\section{References}

1. Lynch, J. Root architecture and plant productivity. Plant Physiol. 1995, 109, 7-13. [CrossRef]

2. Hodge, A.; Berta, G.; Doussan, C.; Merchan, F.; Crespi, M. Plant root growth, architecture and function. Plant Soil 2009, 321, 153-187. [CrossRef]

3. Gasparikova, O.; Waisel, Y.; Eshel, A.; Kafkafi, U. (Eds.) Plant roots-The hidden half. Ann. Bot. 2002, 90, 775-776. [CrossRef]

4. Silva, D.D.; Beeson, R.C., Jr. A large-volume rhizotron for evaluating root growth under natural-like soil moisture conditions. HortScience 2011, 46, 1677-1682. [CrossRef]

5. Reubens, B.; Poesen, J.; Danjon, F.; Geudens, G.; Muys, B. The role of fine and coarse roots in shallow slope stability and soil erosion control with a focus on root system architecture: A review. Trees 2007, 21, 385-402. [CrossRef]

6. Chen, Y.L.; Dunbabin, V.M.; Diggle, A.J.; Siddique, K.H.M.; Rengel, Z. Development of a novel semi-hydroponic phenotyping system for studying root architecture. Funct. Plant Biol. 2011, 38, 355-363. [CrossRef]

7. Chen, Y.L.; Dunbabin, V.M.; Diggle, A.J.; Siddique, K.H.M.; Rengel, Z. Assessing variability in root traits of wild Lupinus angustifolius germplasm: Basis for modelling root system structure. Plant Soil 2012, 354, 141-155. [CrossRef]

8. Chen, Y.; Ghanem, M.E.; Siddique, K.H.M. Characterising root trait variability in chickpea (Cicer arietinum L.) germplasm. J. Exp. Bot. 2017, 68, 1987-1999. [CrossRef]

9. Chen, Y.; Palta, J.; Prasad, P.V.V.; Siddique, K.H.M. Phenotypic variability in bread wheat root systems at the early vegetative stage. BMC Plant Biol. 2020, 20,1-16. [CrossRef] [PubMed]

10. Wang, J.; Chen, Y.; Zhang, Y.; Zhang, Y.; Ai, Y.; Feng, Y.; Moody, D.; Diggle, A.; Damon, P.; Rengel, Z. Phenotyping and Validation of Root Morphological Traits in Barley (Hordeum vulgare L.). Agronomy 2021, 11, 1583. [CrossRef] 
11. Liu, S.; Begum, N.; An, T.; Zhao, T.; Xu, B.; Zhang, S.; Deng, X.; Lam, H.M.; Nguyen, H.T.; Siddique, K.H.M.; et al. Characterization of Root System Architecture Traits in Diverse Soybean Genotypes Using a Semi-Hydroponic System. Plants 2021, $10,2781$. [CrossRef]

12. Figueroa-Bustos, V.; Palta, J.; Chen, Y.; Siddique, K.H.M. Characterization of root and shoot traits in wheat cultivars with putative differences in root system size. Agronomy 2018, 8, 109. [CrossRef]

13. Wu, A.; Fang, Y.; Liu, S.; Wang, H.; Xu, B.; Zhang, S.; Deng, X.; Palta, J.A.; Siddique, K.H.M.; Chen, Y. Root morphology and rhizosheath acid phosphatase activity in legume and graminoid species respond differently to low phosphorus supply. Rhizosphere 2021, 19, 100391. [CrossRef]

14. Jovanovic, M.; Lefebvre, V.; Laporte, P.; Gonzalez-Rizzo, S.; Lelandais-Brière, C.; Frugier, F.; Hartmann, C.; Crespi, M. How the environment regulates root architecture in dicots. In Advances in Botanical Research; Academic Press: Cambridge, MA, USA, 2007; Volume 46, pp. 35-74.

15. Serraj, R.; Krishnamurthy, L.; Kashiwagi, J.; Kumar, J.; Chandra, S.; Crouch, J.H. Variation in root traits of chickpea (Cicer arietinum L.) grown under terminal drought. Field Crop. Res. 2004, 88, 115-127. [CrossRef]

16. Carter, T.E. Breeding for drought tolerance in soybean-where do we stand. In Proceedings of the World Soybean Research Conference IV, Buenos Aires, Argentina, 5-9 March 1989.

17. Prince, S.J.; Murphy, M.; Mutava, R.N.; Durnell, L.A.; Valliyodan, B.; Shannon, J.G.; Nguyen, H.T. Root xylem plasticity to improve water use and yield in water-stressed soybean. J. Exp. Bot. 2017, 68, 2027-2036. [CrossRef]

18. Rincon, C.A.; Raper, J.C.D.; Patterson, R.P. Genotypic differences in root anatomy affecting water movement through roots of soybean. Int. J. Plant Sci. 2003, 164, 543-551. [CrossRef]

19. Lynch, J.P.; Wojciechowski, T. Opportunities and challenges in the subsoil: Pathways to deeper rooted crops. J. Exp. Bot. 2015, 66, 2199-2210. [CrossRef]

20. Siddique, K.; Brinsmead, R.; Knight, R.; Knights, E.; Paull, J.; Rose, I. Adaptation of chickpea (Cicer arietinum L.) and faba bean (Vicia faba L.) to Australia. In Linking Research and Marketing Opportunities for Pulses in the 21st Century, Proceedings of the Third International Food Legumes Research Conference, Adelaide, Australia, 22-26 September 1997; Springer: Berlin, Germany, 2000; pp. 289-303.

21. Varshney, R.K.; Hiremath, P.J.; Lekha, P.; Kashiwagi, J.; Balaji, J.; Deokar, A.A.; Vadez, V.; Xiao, Y.; Srinivasan, R.; Gaur, P.M.; et al. A comprehensive resource of drought- and salinity-responsive ESTs for gene discovery and marker development in chickpea (Cicer arietinum L.). BMC Genom. 2009, 10, 523. [CrossRef]

22. Hudak, C.; Patterson, R. Vegetative growth analysis of a drought-resistant soybean plant introduction. Crop Sci. 1995, $35,464-471$. [CrossRef]

23. Pantalone, V.; Rebetzke, G.; Burton, J.; Carter, T., Jr. Phenotypic evaluation of root traits in soybean and applicability to plant breeding. Crop Sci. 1996, 36, 456-459. [CrossRef]

24. Sadok, W.; Sinclair, T.R. Crops yield increase under water-limited conditions: Review of recent physiological advances for soybean genetic improvement. In Advances in Agronomy; Elsevier: Amsterdam, The Netherlands, 2011; Volume 113, pp. v-vii.

25. Hoogenboom, G.; Peterson, C.M.; Huck, M.G. Shoot growth rate of soybean as affected by drought stress 1. J. Agron. 1987, 79, 598-607. [CrossRef]

26. Schachtman, D.P.; Reid, R.J.; Ayling, S.M. Phosphorus Uptake by Plants: From Soil to Cell. Plant Physiol. 1998, 116, 447-453. [CrossRef]

27. Lynch, J.P.; Brown, K.M. Root strategies for phosphorus acquisition. In The Ecophysiology of Plant-Phosphorus Interactions; Springer: Berlin, Germany, 2008; pp. 83-116.

28. Chen, Y.L.; Dunbabin, V.M.; Diggle, A.J.; Siddique, K.H.M.; Rengel, Z. Phosphorus starvation boosts carboxylate secretion in P-deficient genotypes of Lupinus angustifolius with contrasting root structure. Crop Pasture Sci. 2013, 64, 588-599. [CrossRef]

29. He, J.; Jin, Y.; Turner, N.C.; Chen, Z.; Liu, H.Y.; Wang, X.L.; Siddique, K.H.M.; Li, F.M. Phosphorus application increases root growth, improves daily water use during the reproductive stage, and increases grain yield in soybean subjected to water shortage. Environ. Exp. Bot. 2019, 166, 103816. [CrossRef]

30. Ticconi, C.A.; Delatorre, C.A.; Lahner, B.; Salt, D.E.; Abel, S. Arabidopsis pdr2 reveals a phosphate-sensitive checkpoint in root development. Plant J. 2004, 37, 801-814. [CrossRef]

31. Palta, J.A.; Fillery, I.R.P.; Rebetzke, G.J. Restricted-tillering wheat does not lead to greater investment in roots and early nitrogen uptake. Field Crop. Res. 2007, 104, 52-59. [CrossRef]

32. Aziz, M.M.; Palta, J.A.; Siddique, K.H.M.; Sadras, V.O. Five decades of selection for yield reduced root length density and increased nitrogen uptake per unit root length in Australian wheat varieties. Plant Soil 2016, 413, 181-192. [CrossRef]

33. Gao, X.-B.; Guo, C.; Li, F.-M.; Li, M.; He, J. High Soybean Yield and Drought Adaptation Being Associated with Canopy Architecture, Water Uptake, and Root Traits. Agronomy 2020, 10, 608. [CrossRef]

34. Kotula, L.; Khan, H.A.; Quealy, J.; Turner, N.C.; Vadez, V.; Siddique, K.H.M.; Clode, P.L.; Colmer, T.D. Salt sensitivity in chickpea (Cicer arietinum L.): Ions in reproductive tissues and yield components in contrasting genotypes. Plant Cell Environ. 2015, 38, 1565-1577. [CrossRef] 
35. Sharma, M. Effects of Terminal Drought on Phosphorus Use Efficiency in Four Chickpea Genotypes. This paper is submitted in partial fulfilment of the requirements for a Master of Agriculture Science (Soil Science and Plant Nutrition), AGRI5551-4 Agricultural Sciences Masters Research Dissertation. Master's Thesis, UWA School of Agriculture and Environment, Faculty of Science, The University of Western Australia, Perth, Australia, 2019.

36. Fehr, W.R.; Caviness, C.E.; Burmood, D.T.; Pennington, J.S. Stage of development descriptions for soybeans, Glycine max (L.) Merrill 1. Crop Sci. 1971, 11, 929-931. [CrossRef]

37. Metho, L.A.; Hammes, P.S. The harvest index of individual ears of four South African wheat (Triticum aestivum L.) cultivars. $S$. Afr. J. Plant Soil 2000, 17, 144-146. [CrossRef]

38. Assainar, S.K.; Abbott, L.K.; Mickan, B.S.; Whiteley, A.S.; Siddique, K.H.M.; Solaiman, Z.M. Response of Wheat to a Multiple Species Microbial Inoculant Compared to Fertilizer Application. Front. Plant Sci. 2018, 9, 1601. [CrossRef] [PubMed]

39. Liu, L.; Bai, C.; Chen, Y.; Palta, J.A.; Delhaize, E.; Siddique, K.H.M. Durum wheat with the introgressed TaMATE1B gene shows resistance to terminal drought by ensuring deep root growth in acidic and $\mathrm{Al}^{3+}$-toxic subsoils. Plant Soil 2021, 1-14. [CrossRef]

40. Palta, J.A.; Chen, X.; Milroy, S.P.; Rebetzke, G.J.; Dreccer, M.F.; Watt, M. Large root systems: Are they useful in adapting wheat to dry environments? Funct. Plant Biol. 2011, 38, 347-354. [CrossRef] [PubMed]

41. Shapiro, S.S.; Wilk, M.B. An Analysis of Variance Test for Normality (Complete Samples). Biometrika 1965, 52, 591. [CrossRef]

42. Dayoub, E.; Lamichhane, J.R.; Schoving, C.; Debaeke, P.; Maury, P. Early-Stage Phenotyping of Root Traits Provides Insights into the Drought Tolerance Level of Soybean Cultivars. Agronomy 2021, 11, 188. [CrossRef]

43. Ao, J.H.; Fu, J.B.; Tian, J.; Yan, X.L.; Liao, H. Genetic variability for root morph-architecture traits and root growth dynamics as related to phosphorus efficiency in soybean. Funct. Plant Biol. 2010, 37, 304-312. [CrossRef]

44. He, J.; Jin, Y.; Du, Y.-L.; Wang, T.; Turner, N.C.; Yang, R.-P.; Siddique, K.H.M.; Li, F.-M. Genotypic Variation in Yield, Yield Components, Root Morphology and Architecture, in Soybean in Relation to Water and Phosphorus Supply. Front. Plant Sci. 2017, 8, 1499. [CrossRef]

45. Chen, Y.L.; Dunbabin, V.M.; Postma, J.A.; Diggle, A.J.; Siddique, K.H.M.; Rengel, Z. Modelling root plasticity and response of narrow-leafed lupin to heterogeneous phosphorus supply. Plant Soil 2013, 372, 319-337. [CrossRef]

46. Chen, Y.L.; Dunbabin, V.M.; Postma, J.A.; Diggle, A.J.; Palta, J.A.; Lynch, J.P.; Siddique, K.H.M.; Rengel, Z. Phenotypic variability and modelling of root structure of wild Lupinus angustifolius genotypes. Plant Soil 2011, 348, 345-364. [CrossRef]

47. Lynch, J.P. Root phenotypes for improved nutrient capture: An underexploited opportunity for global agriculture. New Phytol. 2019, 223, 548-564. [CrossRef] [PubMed] 